\title{
Related Factors to Preeclampsia Incidence in Pregnant Women at Lasinrang Regional Hospital Pinrang
}

\author{
Yulis Tinta ${ }^{1 *}$, Vonny Polopadang $^{2}$, Muh.Kardi Rais ${ }^{1}$, Sudirman $^{1}$
}

${ }^{1}$ Public Health Department, STIKES Baramuli Pinrang, Indonesia

${ }^{2}$ Nursing Department, STIKES Baramuli Pinrang, Indonesia

\section{*Corresponding Author}

Yulis Tinta

\section{Article History}

Received: 12.01 .2020

Accepted: 19.01 .2020

Published: 22.01.2020

\begin{abstract}
Preeclampsia is a specific condition in pregnancy characterized by placental dysfunction and maternal response to the presence of stem inflammation with endothelial activation and coagulation. The diagnosis of preeclampsia is based on the presence of hypertension and proteinuria at 20 weeks of gestation. This type of research is an analytic survey with cross-sectional study design. The population in this study are all mothers who come to visit the KIA Poly Room at Lasinrang Pinrang Regional Hospital. The sampling technique used in this study is Accidental Sampling. the number of samples in this study was 134 people. This research will be conducted at Lasinrang Pinrang Regional Hospital in July to August 2019. The results of this study show that there is a relationship between maternal age $(\mathrm{P}=0.023)$, Gravida $(\mathrm{P}=0.0001)$, parity $(\mathrm{P}=0.0001)$ with preeclampsia in the KIA Poly Room of Lasinrang Regional Hospital Pinrang in 2019. Suggestions proposed in this study are Expected to mothers who are at risk age $(<20$ years and $>35$ years), Primigravida (First Pregnancy), Multiparity to better maintain diet and be diligent in carrying out examinations Pregnancy during pregnancy to avoid the incidence of preeclampsia during childbirth.
\end{abstract}

Keywords: Age, Primigravida, Multiparity, Preeclampsia.

\section{INTRODUCTION}

Maternal health is a matter of global development. In some countries, especially developing countries and developing countries, mothers still have a high risk when giving birth. This situation has encouraged the international community to commit to addressing maternal health problems. This commitment is realized by including maternal health as one of the targets in the Sustainable Development Goals [1].

Based on data from the Indonesian Demographic and Health Survey (SDKI) in (2012) for MMR it experienced a significant increase from 228 / 100,000 live births to 359 / 100,000 live births [1]. The aim of the fifth Millennium Development Goals (MDGs), namely the national AKI target in 2013 is 108 / 100,000 live births [2].

South Sulawesi Province (South Sulawesi) entered the top 10 of the list of provinces contributing maternal and infant mortality rates in Indonesia in 2017. This data was released directly by the South Sulawesi Health Office (DHO). The number of maternal deaths in 2017 reached 115 cases, while infant deaths reached 1,059 cases. The death cases are often found in public hospitals (RSU) with a percentage of $79.13 \%$ or as many as 91 cases. Then it happened at home with 9 cases or about $7.83 \%$, then found at the health center with 7 cases or $6.08 \%$, on the road 5 cases or $4.35 \%$, in the Pustu 2 cases or $1.74 \%$ and maternity house 1 cases or $0.87 \%$. [3].

Preeclampsia is influenced by several factors namely, age, parity, history of hypertension, twin pregnancy, obesity, and diabetes mellitus [4]. The role of midwives in preventing preeclampsia in pregnancy is reducing risk factors by early detection of risk factors, giving counseling to mothers to regulate the healthy reproductive age of mothers (20-35 years), but there are still many pregnant women who do not utilize pre-delivery services, especially in rural areas [1]. Risk factors and influence on the progression of preeclampsia [5] namely the factors of maternal age, Gtavida, Parity, gestational age and body mass index (BMI), BMI values above 30 with the category of obesity, the risk of preeclampsia increased to four times.

Copyright @ 2020: This is an open-access article distributed under the terms of the Creative Commons Attribution license which permits unrestricted use, distribution, and reproduction in any medium for non commercial use (NonCommercial, or CC-BY-NC) provided the original author and source are credited. 
The causes of maternal death from reproductive factors include the age of the mother. In a healthy reproduction period, it is known that the safe age for pregnancy and childbirth is 20-35 years. Maternal deaths in pregnant and childbearing women under the age of 20 are in fact 2 to 5 times higher than maternal deaths that occur at ages 20 to 34 years. Maternal mortality has increased again at the age of 35 years [6].

Preeclampsia, a disease of hypertension in pregnancy, is the main disease in primigravida. The risk of preeclampsia is $4.1 \%$ in the first pregnancy and $1.7 \%$ in subsequent pregnancies. Pakar interprets the predilection of preeclampsia more frequently in the first pregnancy as evidence of the presence of immunological factors that play a role in the pathophysiology of preeclampsia [7].

Based on data taken at Lasinrang Pinrang District Hospital in 2016, 3.19\% of 2067 pregnant women gave birth, 2016 had $2.19 \%$ of preeclampsia, and in 2018, there were $2.19 \%$ of 2275 pregnant women giving birth, and in 2018 who experienced preeclampsia as much as $0.94 \%$ of 4255 pregnant women who gave birth. Data for the last 3 months March to May 2019 showed that in March, preeclampsia was $2.43 \%$ of 1148 pregnant women giving birth, in April as much as $1.21 \%$ of 1163 pregnant women who gave birth, and in May as many as $2.72 \%$ of 1496 pregnant women gave birth. From these data, it shows that the incidence of preeclampsia in pregnant women in RSUD Lasinrang Pinrang is still high RSUD Lasinrang Pinrang, 2018. Based on the background, this study aims to determine the factors associated with the incidence of preeclampsia in pregnant women in Lasinrang Pinrang District Hospital in 2019.

\section{METHODS}

This type of research is an analytic survey with cross-sectional study design that is research that aims to identify the variables related to the study and analyze the relationship of independent variables with dependent variables simultaneously in a research time [8]. This research was conducted at Lasinrang Pinrang Regional Hospital on July 25 to August 22, 2019. The population in this study were all mothers who visited the KIA Lasinrang Pinrang Regional General Hospital as many as 3,807 people (March to May 2019).

The sample in this study were some of the mothers who came to visit the KIA Poly Room at RSUD Lasinrang Pinrang, the number of samples in this study was 134 people. The sampling technique used in this study is Accidental Sampling where researchers take samples that happened to be encountered at the time of the study. Types of primary and secondary data collection. Primary data is collected scientifically by using a questionnaire or questionnaire data collection method. Univariate analysis was performed on each variable from the results of the study. In general, this analysis only produces the frequency distribution and percentage of each variable. This analysis was carried out to determine the relationship of dependent and independent variables in the form of a cross-tabulation using the SPSS (Statistical Package and Social Sciences) computerized system with the Chi-Square statistical test.

\section{RESULTS}

General characteristics of respondents are the inherent characteristics of respondents. Characteristics of respondents displayed include age, gravida, parity, and preeclampsia,

Table-1: Distribution of Respondents Based on the Characteristics of Respondents in Pregnant Women in the KIA Poly Room at RSUD Lasinrang Pinrang

\begin{tabular}{|c|c|c|}
\hline Characteristics of Respondents & $\mathrm{n}$ & $\%$ \\
\hline Mother Age Group & & \\
\hline $20-24$ Years old & 10 & 7,5 \\
\hline $25-29$ Years old & 21 & 15,7 \\
\hline $30-34$ Years old & 31 & 23,1 \\
\hline $35-39$ Years old & 38 & 28,4 \\
\hline $40-44$ Years old & 34 & 25,4 \\
\hline Mother Age & & \\
\hline Risky & 72 & 53,7 \\
\hline No risk & 62 & 46,3 \\
\hline Gravida & & \\
\hline Primigravida & 59 & 44 \\
\hline Multigravida & 75 & 56 \\
\hline Parity & & \\
\hline Primiparitas & 62 & 46,3 \\
\hline Multigravida & 72 & 53,7 \\
\hline Preeclampsia & & \\
\hline Yes & 29 & 21,6 \\
\hline No & 105 & 78,4 \\
\hline Source: Primary Data & 2019 \\
\end{tabular}


Based on Table-1 shows that the most were in the age group of 35 - 39 years as many as $38(28.4 \%)$. While at least in the age group of 20-24 years as many as 10 (7.5\%). showed that the most at the age of the risk category were 72 $(53.7 \%)$. While the least at safe age was $62(46.3 \%)$. For Gravida showed that the most was in Multigravida as many as $75(56 \%)$. Whereas the least was Primigravida in 59 (44\%). Parity shows that the most are in Multiparity $72(53.7 \%)$. Whereas the least was in primiparity as much as $62(46.3 \%)$. Preeclampsia showed that the highest number was not preeclampsia as many as $105(78.4 \%)$. While those with preeclampsia were $29(21.6 \%)$.

Table-2: Relationship of Variables (Age, Gravida and Parity) with Preeclampsia in Pregnant Women in the KIA Poly Room at Lasinrang Pinrang Regional Hospital

\begin{tabular}{|c|c|c|c|c|c|c|c|}
\hline \multirow[t]{3}{*}{ Variable } & \multicolumn{4}{|c|}{ Preeclampsia } & \multirow[t]{3}{*}{$\mathrm{N}$} & \multirow[t]{3}{*}{$\%$} & \multirow[t]{3}{*}{$\mathrm{P}$} \\
\hline & \multicolumn{2}{|c|}{ Yes } & \multicolumn{2}{|c|}{ No } & & & \\
\hline & $\mathrm{n}$ & $\%$ & $\mathrm{n}$ & $\%$ & & & \\
\hline \multicolumn{8}{|l|}{ Age } \\
\hline Risky & 21 & 29,2 & 51 & 70,8 & 72 & 100 & \multirow[t]{2}{*}{0,023} \\
\hline No Risk & 8 & 12,9 & 54 & 87,1 & 62 & 100 & \\
\hline \multicolumn{8}{|l|}{ Gravida } \\
\hline Primigravida & 23 & 39 & 36 & 61 & 59 & 100 & \multirow[t]{2}{*}{0,0001} \\
\hline Multigravida & 6 & 8 & 69 & 92 & 75 & 100 & \\
\hline \multicolumn{8}{|l|}{ Parity } \\
\hline Primigravida & 23 & 37,1 & 39 & 62,9 & 62 & 100 & \multirow[t]{2}{*}{0,0001} \\
\hline Multigravida & 6 & 8,3 & 66 & 91,7 & 72 & 100 & \\
\hline
\end{tabular}

Source: Primary Data, 2019

Based on Table- 2 shows that of the 72 respondents at risk age who had preeclampsia were $21(29.2 \%)$ and the age of risk who did not have preeclampsia were 51 (70.8\%). While of the 62 respondents who were not at risk at risk of preeclampsia were $8(12.9 \%)$ and at no risk age who were not at preeclampsia were $54(87.1 \%)$. Statistical test results with chi-square showed the value of $\mathrm{P}=0.023<$ from the value of $\alpha=0.05$, it can be concluded that there is a relationship between maternal age with preeclampsia in the $\mathrm{MCH}$ Poly Room of Lasinrang Pinrang Regional Hospital in 2019. 59 Primigravida respondents with preeclampsia were 23 (23 pre-eclampsia respondents) 39\%) and Primigravida without preeclampsia $36(61 \%)$. Whereas out of 75 Multigravidian respondents who had preeclampsia were $6(8 \%)$ and Multigravida who did not preeclampsia were 69 (92\%). Statistical test results with chi-square show the value of $\mathrm{P}=$ $0.0001<$ from the value of $\alpha=0.05$, it can be concluded that there is a Gravida Relationship with preeclampsia in the KIA Poly Room of Lasinrang Pinrang Regional Hospital in 2019. Parity Relationship shows that from 62 respondents Primiparities with preeclampsia were $23(37.1 \%)$ and Primiparities without preeclampsia were 39 (62.9\%). Whereas out of 72 Multiparity respondents who had preeclampsia as many as $6(8.3 \%)$ and Multiparity who did not preeclampsia as many as $66(91.7 \%)$. Statistical test results with chi-square showed the value of $\mathrm{P}=0.0001<$ of the value of $\alpha=0.05$, it can be concluded that there is a Parity Relationship with preeclampsia in the KIA Poly Room of Lasinrang Pinrang Hospital in 2019.

\section{DISCUSSION}

Preeclampsia is a specific condition in pregnancy that is characterized by placental dysfunction and maternal response to systemic inflammation with endothelial activation and coagulation. The diagnosis of preeclampsia is based on the presence of hypertension and proteinuria at gestational age above 20 weeks [9]. Risk factors and influence on the progression of preeclampsia according to [5] namely: the term age is defined as the length of a person's presence measured in units of time in terms of chronological terms, normal individuals who show the same degree of anatomical and physiological development [10]. Age is the length of time of life or existing (since birth or held) [6]. The causes of maternal death from reproductive factors include the age of the mother. In a healthy reproduction period, it is known that the safe age for pregnancy and childbirth is 20-35 years. Maternal deaths in pregnancy and childbirth women under the age of 20 are in fact 2 to 5 times higher than maternal deaths that occur at ages 20 to 34 years. Maternal mortality has increased again at the age of 35 years [6].

The results of the study in Table-2 show that respondents based on age in the MCH Poly Room of RSUD Lasinrang Pinrang in 2019 were most at risk age as many as $72(53.7 \%)$. While the least at the age of no risk were 62 $(46.3 \%)$. that of the 72 respondents at risk age who had preeclampsia were $21(29.2 \%)$ and those who were not preeclamptic were $51(70.8 \%)$. While of the 62 respondents who were not at risk at risk of preeclampsia were $8(12.9 \%)$ and at no risk age who were not at preeclampsia were $54(87.1 \%)$.

Statistical test results with chi-square show the value of $\mathrm{P}=0.023<$ of the value of $\alpha=0.05$, it can be concluded that there is a Mother Age Relationship with preeclampsia in the KIA Poly Room of Lasinrang Pinrang Regional Hospital 
in 2019. This is due to the mature reproductive system and ready to accept the occurrence of pregnancy, namely in the age range of 20-35 years. The process of maternal pregnancy under the age of 20 can trigger preeclampsia because of pregnancy poisoning because it is not ready for use in the reproductive system. While pregnancies over the age of 35 there are changes in the uterine tissues and the inflexibility of the birth canal, which makes the mother vulnerable to hypertension and preeclampsia. This research is in line with research conducted by Denantika [11] in Dr. M. Djamil Padang produced that the proportion of mothers aged in the high-risk age category ( $<20$ years and $>35$ years) and suffering from preeclampsia was 4.43 times more than those without preeclampsia. After analyzing through the chisquare test, it was concluded that there was a significant relationship between maternal age and the incidence of preeclampsia $(\mathrm{p}<0.05)$.

Gravida is one component of parity status that is often written with the G-P-Ab notation, where G represents the number of pregnancies, $\mathrm{P}$ represents the number of parities, and $\mathrm{Ab}$ represents the number of abortions. Experts interpret the incidence of preeclampsia more often in the first pregnancy as evidence of the presence of immunological factors that play a role in the pathophysiology of preeclampsia [7].

The results of the study in Table- 2 show that respondents based on gravida in the MCH Poly Room of RSUD Lasinrang Pinrang in 2019 were mostly in Multigravida at 75 (56\%). While the lowest was in Primigravida as many as 59 (44\%). Based on table .7 shows that of the 59 Primigravida respondents who were preeclampsia were $23(39 \%)$ and Primigravida who were not preeclampsia were $36(61 \%)$. Whereas out of 75 Multigravidian respondents who had preeclampsia were $6(8 \%)$ and Multigravida who did not preeclampsia were $69(92 \%)$.

Statistical test results with chi-square showed the value of $P=0.0001<$ from the value of $\alpha=0.05$, it can be concluded that there is a Gravida Relationship with preeclampsia in the KIA Poly Room of Lasinrang Pinrang Hospital in 2019. This is supported by immunological theory, mentioned that in pregnancy the first time there is the formation of blocking antibodies to antigens whose results are not perfect so that it can inhibit the process of invasion of the mother's spiral arteries by the trophoblast to a certain extent so that as a drug is able to interfere with placental function. Reduction of prostacyclin vasodilator excretion by endothelial cells of the placenta and increased secretion of breakthrough cause a decrease in generalized vasoconstriction and aldosterone secretion. This study is in line with research conducted by Marniati [12]. The results of the study were obtained with preeclampsia (33.9\%), age variable with the incidence of preeclampsia ( $\mathrm{p}=0.001$ and $\mathrm{OR}=9.4$ ), it can be concluded that there is a relationship between age, gravida status, gestational age, with pre-eclampsia at the general hospital Dr. Zaionel Abidin Province of Aceh.

Parity is the birth of a baby that is able to survive. Parity is achieved at 20 weeks' gestation or 500 grams of fetal weight. Women with high parity are risk factors for anemia in pregnancy, diabetes mellitus (DM), hypertension, malpresentation, placenta previa, uterine rupture, low birth weight (LBW), premature babies can even cause death in children [13]. The results of the study in table 1 show that respondents based on Parity in the MCH Poly Room of RSUD Lasinrang Pinrang in 2019 were mostly in Multiparity as many as 72 (53.7\%). While the lowest was in primiparity as much as $62(46.3 \%)$. Based on Table-2 shows that of the 62 Primiparitas respondents with preeclampsia as many as 23 $(37.1 \%)$ and Primiparity without preeclampsia as many as $39(62.9 \%)$. Whereas out of 72 Multiparity respondents who had preeclampsia were $6(8.3 \%)$ and Multiparity who did not preeclampsia were $66(91.7 \%)$.

Statistical test results with chi-square shows the value of $\mathrm{P}=0.0001<$ of the value of $\alpha=0.05$, it can be concluded that there is a Parity Relationship with preeclampsia in the KIA Poly Room of Lasinrang Pinrang Regional Hospital in 2019. Multiparity is at risk in the incidence of postpartum hemorrhage due to by the uterine muscles that are often stretched so that the walls thin and contractions become weak. This resulted in the incidence of postpartum hemorrhage being 4 times greater in multiparity where the incidence was $2.7 \%$ [14]. This study is in line with research conducted by Andriani \& Rusnoto [15], showing that the majority of respondents had a multiparous parity of 18 people $(60 \%)$, and primiparous as many as 12 people $(40 \%)$. So there is a relationship of parity with the incidence of severe preeclampsia in UPT Japanese health centers ( $\mathrm{p}$-value $=0.001)$.

\section{CONCLUSION}

Based on the discussion above, the conclusion that can be drawn in this study is that there is a relationship between maternal age with preeclampsia in the MCH poly space in Lasinrang Pinrang Regional Hospital in 2019, there is a Gravida Relationship with preeclampsia in the MCH Poly Room in Lasinrang Regional Hospital Pinrang in 2019, and there is a Parity Relationship with preeclampsia in 2019, there is a Gravida Relationship with preeclampsia in the MCH Poly Room of Lasinrang Pinrang Regional Hospital in 2019, Polyclinic KIA room Lasinrang Pinrang Regional Hospital in 2019. Based on the above conclusions, the advice proposed in this study is expected to mothers who are at risk age ( $<20$ years and $>35$ years) to better maintain their eating patterns during pregnancy to avoid the occurrence of preeclampsia at the time of childbirth, it is hoped that the relevant agencies will continue to conduct socialization related to preeclampsia specifically to Primigravida (First Pregnancy) mothers. 


\section{REFERENCES}

1. Ministry of Health Republic of Indonesia. (2015). Kesehatan dalam Kerangka Sustainable Development Goals (SDGs). Jakarta.

2. Ministry of Health Republic of Indonesia. (2014) .Profil Kesehatan Indonesia Tahun 2014. Jakarta: Kementerian Kesehatan Republik Indonesia.

3. Provincial Health Office South Sulawesi. (2017). Profil Kesehatan Provinsi Sulawesi Selatan Tahun 2016. Makassar : Dinas Kesehatan Provinsi Sulawesi Selatan.

4. Bothamley, J., \& Boyle, M. (2012). Patofisiologi dalam kebidanan. Jakarta: EGC.

5. Pribadi, A., Mose, J., \& Anwar, A. D. (2015). Kehamilan Resiko Tinggi. Jakarta: CV. Sagung Seto.

6. Prawirohardjo, S. (2008). Ilmu Kebidanan. Jakarta: PT. Bina Pustaka.

7. Hernández-Correa, J. C. (2010). Maternal mortality and risk factors at the community level. Economic Working Paper. Departement of Economics. Michigan: Western Michigan University.

8. Notoatmodjo, S. (2012). Metodologi penelitian kesehatan (Cetakan VI). Jakarta: Penerbit PT. Rineka Cipta.

9. POGI. (2014). Pelatihan Klinik Asuhan Persalinan Normal. Jakarta: JNPK-KR DEPKES RI

10. Wibowo, R. (2006). Proteinuria dalam Ilmu Penyakit Dalam Jilid 1 edisi 5. Jakarta: Penerbit FKUI.

11. Denantika, O., Serudji, J., \& Revilla, G. (2015). Hubungan Status Gravida dan Usia Ibu terhadap Kejadian Preeklampsia di RSUP Dr. M. Djamil Padang Tahun 2012-2013. Jurnal Kesehatan Andalas, 4(1).

12. Marniati, M., Rahmi, N., \& Djokosujono, K. (2019). Analisis Hubungan Usia, Status Gravida dan Usia Kehamilan dengan Pre-Eklampsia pada Ibu Hamil di Rumah Sakit Umum dr. Zaionel Abidin Provinsi Aceh Tahun. Journal Of Healthcare Technology And Medicine, 2(1), 99-109.

13. Varney, H. (2010). Buku Ajar Asuhan Kebidanan Edisi 4. Jakarta. EGC.

14. Niswati, E. (2012). Suhartatik. Karakteristik multipara terhadap kejadian haemoragic post partum (HPP) di RSUD Haji Makassar. Jurnal Ilmiah Kesehatan Diagnosis, 1(2), 1-6.

15. Andriani, D., \& Rusnoto, R. (2019). Hubungan antara paritas, riwayat kehamilan, dan asupan kalsium dengan kejadian Pre eklampsia berat. Jurnal Ilmu Keperawatan dan Kebidanan, 10(2), 358-368. 